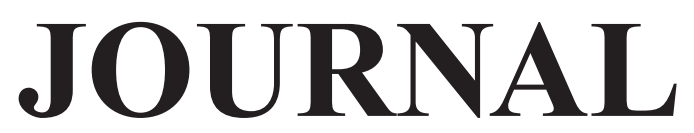

OF

\title{
PESTICIDE SCIENCE
}

Volume 32

2007

\begin{tabular}{|c|c|c|c|}
\hline \multicolumn{4}{|c|}{ EDITORIAL BOARD } \\
\hline \multicolumn{4}{|c|}{ Editor-in-Chief: } \\
\hline *Miki AKAMATSU & Tetsu ANDO & Tsutomu ARIE & Tadao AsAmi \\
\hline Makoto FUJIMURA & Takuo FujisAwA & Takanori HARADA & Andrew HinTON \\
\hline Toshiaki HosHinO & Kazuhito Ітон & Shinzo KaGABU & *Arata KatAYAMA \\
\hline Mitsunori KIRIHATA & Shin KuROGOCHI & Eiichi KUWANO & *Kazuhiko MATSUDA \\
\hline Hiroshi MATsUMOTO & Toru МгҮАмОто & ¡*Hideto MiYOSHI & *Kazuhiko МотовА \\
\hline †*Yoshiaki NAKAGAWA & Kouji NAKAMURA & Akira NAKAYAMA & *Takeo OHкOUCHI \\
\hline Toshiro Онтsuво & Masato OMATsU & Yoshihisa OzoE & Isao SAITO \\
\hline Mitsuru SASAKI & Tsutomu SHIMizU & Takahiro SHIOTSUKI & Toshiji TADA \\
\hline *Hiroto TAMURA & ${ }^{\dagger *}$ Chihiro TANAKA & Hiroshi TANAKA & *Hideki UNEME \\
\hline Craig E. WheELock & Hiroki Y АMAMOTO & Yasuhiro Yogo & Koichi YoneYAma \\
\hline & * Standing Editors & ${ }^{\dagger}$ Managing Edit & \\
\hline
\end{tabular}

\section{Published by the Pesticide Science Society of Japan}

c/o Japan Plant Protection Association

1-43-11 Komagome, Toshima-ku, Tokyo 170-8484, Japan 



\title{
Contents of Volume 32, 2007
}

\author{
No. 1
}

\section{Part I (in English) \\ Review}

Efficacy evaluation of plant protection products at EU level: Data requirements and evaluation principles

\section{Original Articles}

Anna E. KalAmarakis and Emilia MARKELloU

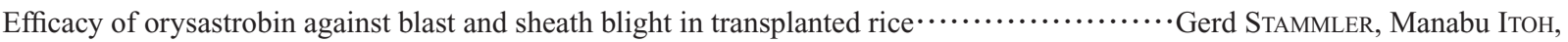

Isao Hino, Akihide Watanabe, Kenichi KoJIma, Masatoshi Motoyoshi, Andreas Koch and Egon HadeN Influence of fluorinated surfactants on the efficacy of some post-emergence sulfonylurea herbicides

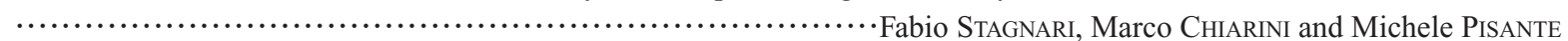

Characterization of mRNAs encoding ethylene biosynthesis enzymes in the root holoparasitic plants Orobanche

...................... Sarawut RungmeKarat, Mayumi IINO, Masanao SATO, Tsubasa TAKAHASHI, Tomohide NATSUAKI,

Yasutomo TAKEUCHI and Koichi YONEYAMA

Construction and validation of an insecticide resistance-associated DNA microarray

\section{Notes}

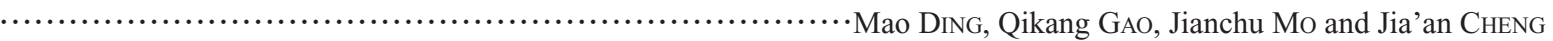

Synthesis and herbicidal activity of alkyl 1-(3-trifluoromethylphenoxyacetoxy)-1-substituted methylphosphonates

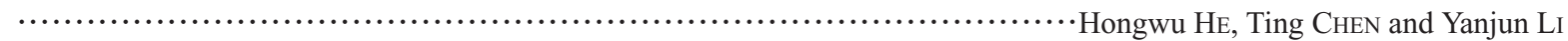

Synthetic procedure for modifying the amine part of carpropamid: Changing 4-chlorophenethylamine to alkyl,

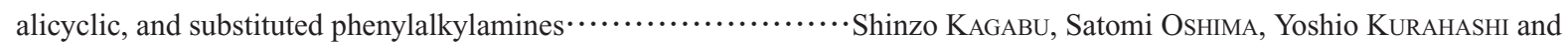

Isamu YAMAGUCHI

Synthesis and nematocidal activity of ascaridole derivatives against Meloidogyne incognita and Aphelenchoides

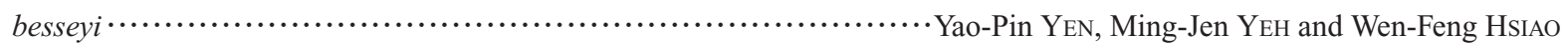

Acknowledgments

Part II (in Japanese)

Abstracts for Original Articles

\section{Commentary}

The role of Food Safety Commission in the introduction of Positive List System for Agricultural Chemical Residues

in Foods -Yoshinobu NOZAKA

\section{Letter to Members}

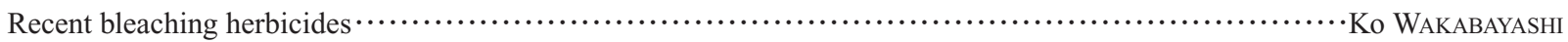

Symposia

Book Review

Society News

No. 2

\section{Part I (in English)}

Review

Insecticide resistance monitoring and evaluation in disease transmitting mosquitoes

\section{Original Articles}

Michael Coleman and Janet Hemingway

Biochemical basis of selective disease controlling activity of mepanipyrim

Control efficacy of validamycin A against Fusarium wilt correlated with the severity of phytotoxic necrosis formed 
A novel mutant acetolactate synthase gene from rice cells, which confers resistance to ALS-inhibiting herbicides

. Atsunori FuKUDA and Yoshiyuki TANAKA

Synthesis and anti-juvenile hormone activity of ethyl 4-(2-benzylalkyloxy)benzoates and their enantiomers

- Kenjiro Furuta, Kiyo Ashibe, Hiromitsu Shirahashi, Norihiro Fujita, Haruna Yamashita,

Naotaka YAMADA and Eiichi KUWANO

Effect of culture age on mepanipyrim-mediated inhibition of pectinase secretion in Botrytis cinerea

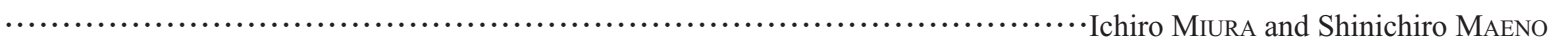

Synthesis of new bicyclo[4.1.0]heptane-2,4-dione derivatives and their herbicidal activity

............... Hiroyuki Adachi, Akiyoshi UedA, Toshio Aimara, Kazuyuki TomidA, Takashi Kawana and Hideo HosaKa

Notes

An environmentally acceptable method for assaying the inhibition of $\alpha$-amylase induction

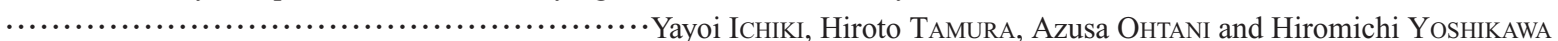

Isolation of an insecticidal compound oxalicine B from Penicillium sp. TAMA 71 and confirmation of its chemical

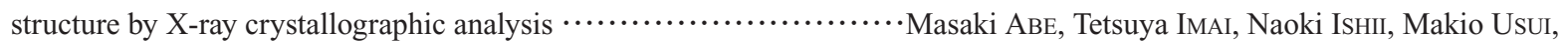

Toru OKUDA and Toshikazu OKI

Is pyridylmethyl group of imidacloprid replaceable with fluoroalkyl moiety as a hydrogen-bond acceptor?

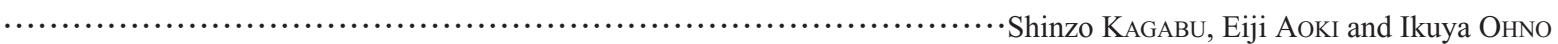

Isolation and structural properties of aerial mycelium differentiation-inhibitory substances against Streptomyces

scabiei causing potato common scab ….... Masahiro NATSUME, Atsushi Ooshiro, Tsuneki TAKAHASHI, Fumihiko KoKIDO, Makoto Hashimoto, Yuu AoKI, Hiroshi Kawaide and Hiroshi ABE

\section{The Society Award Lectures (abstract)}

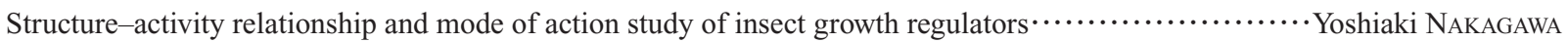

Development of a novel fungicide, cyflufenamid $\cdots \cdots \cdots \cdots \cdots \cdots \cdots$. Shinsuke SANO, Isamu KASAHARA and Homare YAMANAKA

Development of estimation methods for movement of applied pesticide in farmlands

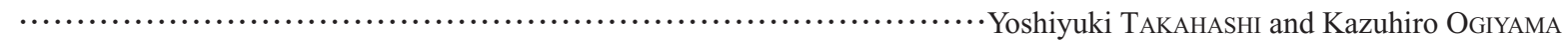

Development and commercialization of Trichoderma asperellum SKT-1 (Ecohope ${ }^{\circledR}$ ), a microbial pesticide

...................... Kozo Nagayama, Satoshi Watanabe, Kazuo KumaKura, Takeshi IchiKawa and Takahiro Makino

Part II (in Japanese)

The Society Award Lectures

Abstracts for Original Articles

\section{Commentary}

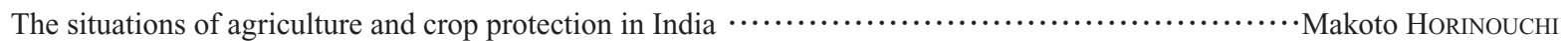

\section{Letter to Members}

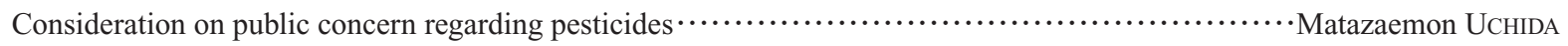

Symposia

Society News

No. 3

\section{Part I (in English)}

Reviews

Environmental fate and toxicology of fipronil

.................... Amrith S. Gunasekara, Tresca Truong, Kean S. Goh, Frank Spurlock and Ronald S. TJeerdema

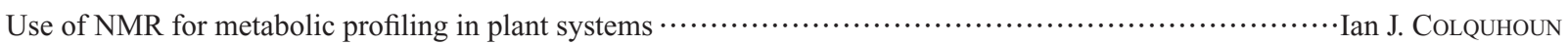

\section{Original Articles}

Preliminary investigation of the disposition of the molluscicidal saponin deltonin from Balanites aegyptiaca in a snail

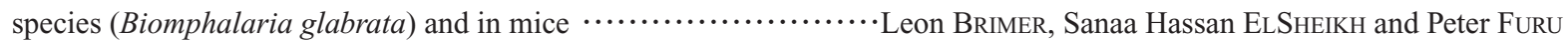

Mode of action of Trichoderma asperellum SKT-1, a biocontrol agent against Gibberella fujikuroi 
Reduction of dieldrin concentration in cucumber fruits using Cucurbita rootstocks and activated carbon Yoshiko Hashimoto

Rootstock control of fruit dieldrin concentration in grafted cucumber (Cucumis sativus)

Design and release profile of timed-release coated granules of herbicide

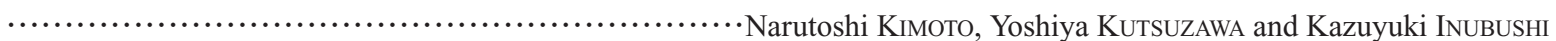

Action of fentrazamide on protein metabolism and cell division in plants

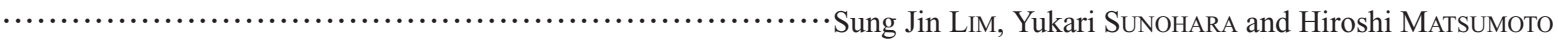

Notes

Synthesis and herbicidal activity of a pentafluorosulfanyl analog of trifluralin

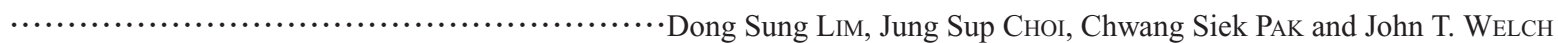

Preparation of 5-chloro-6-fluoroimidacloprid analogs and comparison of their insecticidal activity in a laboratory test

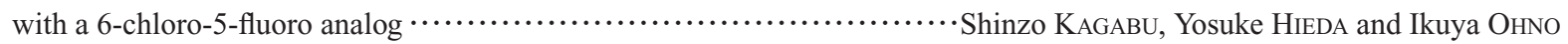

Volatile sesquiterpenes emitted from leaves of Polygonum longisetum treated with jasmonic acid and its amide conjugates

..Shigeru TAMOgAmi, Yasuhiro NARITA, Shigeharu SuZuKI, Tomoyuki NishizAWA, Hidetoshi HANAI and Masana NOMA

\section{Technical Report}

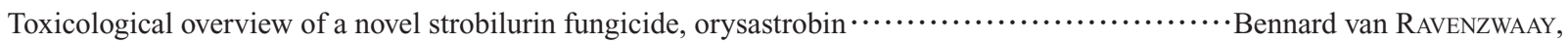
Masako AkiYama, Robert Landsiedel, Heinz KieczKA, Georgia CunHA, Steffen SchNEIDER, Uwe Kaspers, Wolfgang KaUFMANN and Masaki OsAWA

\section{The Society Award Lectures (abstract)}

Mechanisms of action of insecticides on ligand-gated ion channels . Makoto IHARA

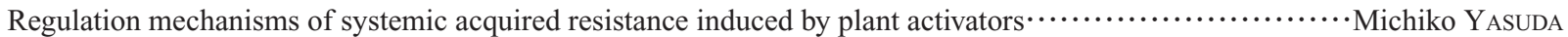

Part II (in Japanese)

The Society Award Lectures

Note (with abstract in English)

Matrix effect of spinach on agricultural chemical residue analysis by a commercially available ELISA kit

Abstracts for Original Articles

Shoko Amano, Shinobu Suga and Sadanori SaWANo

\section{Commentary}

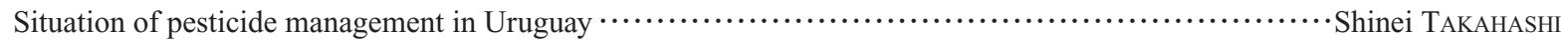

\section{Letter to Members}

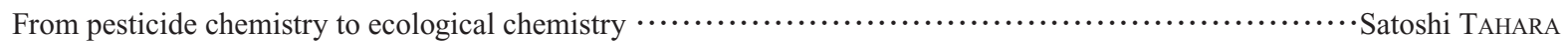

Minireviews: Perspective on application of supercritical fluid extraction to pesticide residue analysis

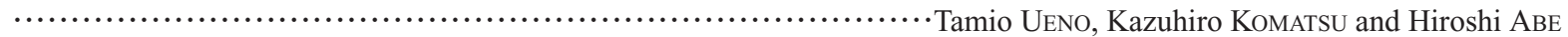

Pesticide residue analysis using supercritical fluid extraction — from a viewpoint of crop production Takashi ANDO

Pesticide multiresidue analysis using supercritical fluid extraction — from a viewpoint of food hygiene

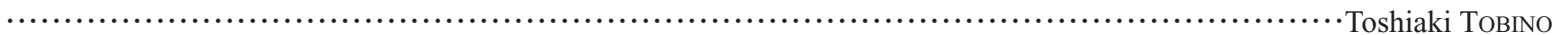

Pesticide residue analysis using supercritical fluid extraction — from a viewpoint of method development -Satoru Neмото

Automatic extraction system for pesticide residues in food using supercritical carbon dioxide Yoshiteru HoRIKAWA

\section{No. 4}

\section{Part I (in English) \\ Reviews}

Molecular physiology of crustacean and insect neuropeptides $\cdots \cdots \cdots \cdot$... Joffre MERCIER, Daniel DouCET and Arthur RETNAKARAN 
Earthworm biomakers of pesticide contamination: Current status and perspectives

\section{Original Articles}

Resistance of Aphis gossypii (Homoptera: Aphididae) to selected insecticides on cotton from five cotton production regions in Shandong, China $\cdots \cdots \cdots \cdot$ Kai-Yun WANG, Qing-Long GuO, Xiao-Ming XIA, Hong-Yan Wang and Tong-Xian LiU

Effects of the structures of ecdysone receptor (EcR) and ultraspiracle (USP) on the ligand-binding activity of the

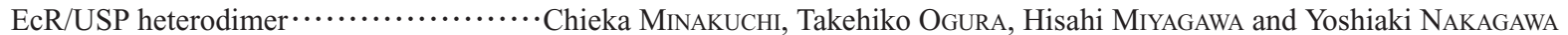

Functional analysis of transgenic rice plants expressing a novel mutated ALS gene of rice

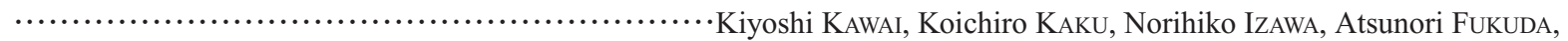
Yoshiyuki TANAKA and Tsutomu SHIMIZU

Aerobic metabolism and adsorption of pyrethroid insecticide metofluthrin in soil

Rika KodAKa, Yusuke Suzuki, Terumi Sugano and Toshiyuki Katagi

Design and release profile of timed-release coated granules of systemic insecticide

Note -Narutoshi KIмоTo, Atsushi TAKAHASHI and Kazuyuki InUBUSHI

Spinosad bait treatments as alternative to malathion to control the Mediterranean fruit fly Ceratitis capitata (Diptera: Tephritidae) in the Mediterranean Basin …..............Patricia CHUECA, Helga MonTÓN, José Luís RIPOLLÉs, Pedro Castañera, Enrique Moltó and Alberto Urbaneja

\section{Correction}

Part II (in Japanese)

\section{Commentary}

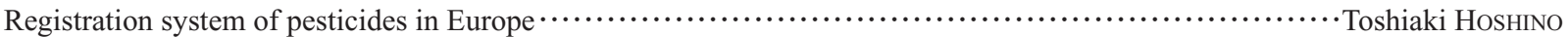

\section{Letter to Members}

A private view on agricultural chemicals

Minireviews: Measures taken toward the enforcement of the positive list system for

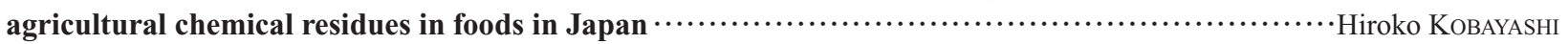

Practical consideration on the new regulatory system for residual agricultural chemicals in Japan …....... Takashi WATANABE

Overview of the pesticide residue violations of imported foods after the enforcement of the positive list system for

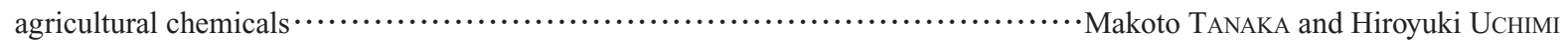

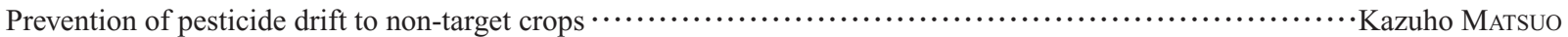

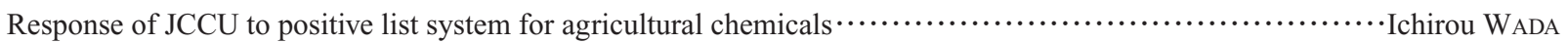

Keyword Index to Volume 32, 2007

Author Index to Volume 32, 2007

Contents of Volume 32, 2007 